\title{
CORRIGENDUM
}

\section{Organic electronic ratchets doing work}

Erik M. Roeling, Wijnand Chr. Germs, Barry Smalbrugge, Erik Jan Geluk, Tjibbe de Vries, René A. J. Janssen and Martijn Kemerink

Nature Materials 10, 51-55 (2011); published online: 12 December 2010; corrected after print: 17 December 2010.

In the version of this Letter originally published online, the $y$-axis of Figure $3 \mathrm{~b}$ should have read 'Output power $(\mu \mathrm{W})$ ' instead of 'Output power $(\mathrm{mW})$ '. This error has now been corrected in the HTML and PDF versions of the text. 